\title{
Studies on the Physico-Chemical Parameters of Bilawali Tank, Indore (M.P.) India
}

\author{
P.Choudhary ${ }^{1}$, N.K.Dhakad ${ }^{2}$, R. Jain ${ }^{3}$ \\ 1. (Zoology department, Govt. P. G. college, Dhar, M.P., India) \\ 2. (Add. Director, Higher education, Indore division, Indore, M.P., India) \\ 3. (Zoology department, Holkar Science College, Indore, M.P., India)
}

\begin{abstract}
This paper deals with an assessment of quality of water tank, an analysis on the physico-chemical parameters of Bilawali Tank water, Indore (M.P.), India. The findings of the analysis will prove to be quite informative, to the daily consumers of the water. Water samples were collected in three different seasons. Water samples were analyzed for physico-chemical parameters including temperature, turbidity, $\mathrm{pH}$, total dissolved solids, alkalinity, total hardness, phosphate and nitrate. Their results were compared with WHO, BIS drinking water standards.
\end{abstract}

Key words: Bilawali Tank, Physico-chemical parameters, WHO, BIS.

\section{Introduction}

Water is an incredibly important aspect of our daily life. Every day we drink water, cook with water, bath in water and participate in many activities involving water. It is essential for all dimensions of life.

Water is one of the abundantly available substances in nature. It is an important and life sustaining drinks to human and is essential for the survival of all the organisms. Living organisms require large quantities of water for their sustenance.

Several contributors are to be noted who have made achievement in the field of hydrobiology in India and abroad. Some of the important and recent contributors are Eletta and Adekola(2005) ${ }^{[1]}$, Kiran $(2010)^{[2]}$, Raut et.al; $(2011)^{[3]}$, Naik et.al; $(2012)^{[4]}$, Bahekar and There $(2013)^{[5]}$, Mahajan and Tank (2013) ${ }^{[6]}$ who have studied the physico-chemical parameters of the various water bodies.

The physical parameters (temperature, turbidity) of water have significant influence on aquatic life. They determine the type of organisms that can live there. In this reference the physical parameters of Bilawali Tank such as Water Temperature, Turbidity were seasonally determined. The chemical nature of water affects the distribution of aquatic organisms. It is therefore necessary to determine the chemical parameters (pH, TDS, Total Alkalinity, Total Hardness, Chloride, Phosphate, and Nitrate) of water before attempting to study the animals and plants living in it. Water quality of aquatic water body changes continuously in accordance with the physical and biological parameters. The present study aims at acquiring the first hand knowledge of the water quality of Bilawali tank in order to assess its production potential. The findings of the analysis will prove to be quite informative, to the daily consumers of the water.

\section{Study Area}

Indore is the largest city of Madhya Pradesh in central India. It is situated between $22^{\circ} 20^{\prime \prime} \mathrm{N}$ to $23^{\circ}$ $05^{\prime \prime} \mathrm{N}$ latitude and $75^{\circ} 25^{\prime \prime} \mathrm{E}$ to $75^{\circ} 15^{\prime \prime} \mathrm{E}$ longitude. Bilawali tank is situated in the southwest direction of Indore at Khandwa road near Sant Shri Asharamji Bapu Ashram. It is situated $6 \mathrm{~km}$ away from Indore in Madhya Pradesh. The catchment area of tank is 117 ha. and water area is 69 ha. The tank was completely made in 1914 by Maharaja Tukoji Rao Holkar under the supervision of Sri Geddes. After its completion, the tank was connected to pipliya pala talab by means of a canal near the Limbodi village. It is based on the plan of the contemporary resident Shri Bhojket in 1905. The tank used to provide water to the textile industries in the past. Now-a-days the tank caters to the need of a particular area for its various uses like drinking, fish culture etc.

\section{Methodology}

Great care was taken in the collection of water samples. The water samples were collected seasonally from the selected sampling sites early morning between 7 A.M to 10 A.M. This study were carried out at four selected sampling sites identified in the East, West, North, and South directions. The test which has to be conducted at sites like temperature, turbidity and $\mathrm{pH}$ were immediately done at site and the rest of the parameters collected water samples were kept in an ice box and were brought to the laboratory for analysis. All parameters were analyzed as per the standard methods of APHA (1998) ${ }^{[7]}$. 


\section{Results And Discussion}

Table 1 shows the range of different physico-chemical parameters important to deciding the drinking water quality of Tank. The reported values are also compared with quality standards as proposed by WHO $(1993)^{[8]}$ and BIS (1991) ${ }^{[9]}$.

\subsection{TEMPERATURE}

Temperature measurements are very useful in understanding the trend of physical, chemical and biological activities which are enhanced/ retarded by the variation of temperature

In the present study the water temperature range of Bilawali Tank was recorded between 16 ${ }^{\circ} \mathrm{C}$ to $27.8^{\circ} \mathrm{C}$. Where as WHO (1993) did not recommend any definite temperature value for drinking water. A temperature of about $40^{\circ} \mathrm{C}$ is permissible limit for drinking water (BIS 1991). According to Jhingran the best suitable temperature range for fish culture is $25-31^{\circ} \mathrm{C}$. Temperature below $14^{\circ} \mathrm{C}$ and above $39.5^{\circ} \mathrm{C}$ is harmful for fish (Hossain et.al., 2008 ) $^{[10]}$. Hence it can be concluded that the water temperature of Bilawali Tank is suitable for both drinking purpose and fish production.

\subsection{TURBIDITY}

The range of turbidity of Tank was recorded from 6 NTU to 22 NTU. It was slightly above the acceptable limit of BIS 1991. The WHO recommendation of turbidity is 5-25 NTU and BIS recommendation is $10 \mathrm{NTU}$. Thus the water needs to be treated before being used for drinking purpose.

\section{$4.3 \mathrm{pH}$}

In the current study the $\mathrm{pH}$ was found ranging between 7.0 and 8.3. $\mathrm{pH}$ as such has no adverse effect on health, however a lower value below 4 will produce sour taste; and a higher value above 8.5 an alkaline taste. $\mathrm{pH}$ range from 6.5 to 7.5 is most favorable for production in a water body. The WHO and BIS recommendation of $\mathrm{pH}$ is 6.5- 8.5. In the current study the $\mathrm{pH}$ range is a safe for fish production and drinking water.

\subsection{TOTAL DISSOLVED SOLIDS}

In the present study TDS varied from $290 \mathrm{mg} / \mathrm{l}$ to $328 \mathrm{mg} / \mathrm{l}$. The BIS (1991) has set desirable limit of TDS value to be $500 \mathrm{mg} / \mathrm{l}$ in potable water. However the permissible limit is $2000 \mathrm{mg} / \mathrm{l}$ in the absence of any alternative source in water. According to WHO (1993), the standard permissible limit for TDS is $1000 \mathrm{mg} / \mathrm{l}$. Water at a TDS level of above $500 \mathrm{mg} / \mathrm{l}$ is unsuitable for flora and tastes unpleasant to drink. In the present study TDS values were found well within the standard permissible limit which accounts for its palatability.

\subsection{ALKALINITY}

In the present study the total alkalinity ranged from $138 \mathrm{mg} / \mathrm{l}$ to $198 \mathrm{mg} / \mathrm{l}$. BIS has set the desirable limit of alkalinity for drinking water to be $200 \mathrm{mg} / \mathrm{l}$ and the permissible value has been prescribed to be 600 $\mathrm{mg} / \mathrm{l}$ in the absence of any alternative source; however according to WHO (1993) it is to be $200 \mathrm{mg} / \mathrm{l}$. In the present study the total alkalinity values was found to be well within the standard permissible limit of BIS (1991).

\subsection{TOTAL HARDNESS}

In the present study the total hardness value ranged from $132 \mathrm{mg} / \mathrm{l}$ to $187 \mathrm{mg} / \mathrm{l}$. The standard permissible limit of total hardness value of drinking water set by BIS (1991) is $300 \mathrm{mg} / \mathrm{l}$. According to WHO (1993) its value is $500 \mathrm{mg} / \mathrm{l}$. This proves that the water of Bilawali Tank is most suitable for the growth and production of fish.

\subsection{CHLORIDE}

In the present study chloride value ranged from $20 \mathrm{mg} / \mathrm{l}$ to $64 \mathrm{mg} / \mathrm{l}$. BIS (1991) have set a desirable limit of chloride in drinking water to be $250 \mathrm{mg} / \mathrm{l}$ and permissible value has been prescribed to be $1000 \mathrm{mg} / \mathrm{l}$ in the absence of any alternative source. Whereas according to WHO (1993), it is $250 \mathrm{mg} / \mathrm{l}$. The tank water show chloride content was below than the permissible limit prescribed by WHO and BIS standards. Hence, the water of tank is quite suitable for drinking, domestic and aquaculture purposes.

\subsection{PHOSPHATE}

During the present investigation phosphate values were found ranging between $0.021 \mathrm{mg} / \mathrm{l}$ to 0.071 $\mathrm{mg} / \mathrm{l}$. There is no BIS standard permissible limit for phosphate for drinking water, while WHO (1993) has fixed it to be $0.1 \mathrm{mg} / \mathrm{l}$. If level becomes too high, plant growth can accelerate resulting in the dense growth of algae and plants in the water body. Accelerated and uncontrolled plant growth impairs fishing, boating and other 
recreational uses of natural water. The phosphate range in the Bilawali Tank water was within the permissible limit prescribed by WHO, hence tank water is suitable for drinking purposes.

\subsection{NITRATE}

During the present investigation nitrate values were found ranging between $0.21 \mathrm{mg} / \mathrm{l}$ to $1.28 \mathrm{mg} / \mathrm{l}$. WHO (1993) has fixed the value of nitrate in drinking water to be $50 \mathrm{mg} / \mathrm{l}$ and BIS (1991) has set a desirable limit of nitrate in drinking water to be $45 \mathrm{mg} / \mathrm{l}$ and permissible value has been prescribed to be $100 \mathrm{mg} / \mathrm{l}$ in the absence of any alternative source. In the present study nitrate values of tank water were found to be less than the standard permissible limits of BIS (1991) and WHO (1993). Its value indicates pollution free, good water quality wise and suitable for drinking purpose.

\section{Conclusion}

The present study show detailed physico-chemical parameters and quality of water in Bilawali Tank, Indore. The present investigations indicates that all parameters (except turbidity) were within the permissible limits as per standards proposed by WHO (1993) and BIS (1991). It indicates that the normal treatment at filtration unit makes the tank water potable for drinking. All the parameters are quite suitable for growth of Fish. Finally, it is concluded that the water of Tank is quite suitable for human consumptions.

\section{References}

[1] O. A. A. Eletta and F. A. Adekola, Studies of the physical and chemical properties of Asa River water, Kwara state, Nigeria. Science Focus 10(1), 2005, 72-76.

[2] B. R. Kiran, Physico-chemical characteristics of Fish Ponds of Bhadra project at Karnataka, India. Rasayan J. Chem 4, 2010,671 676.

[3] K.S. Raut, S. E. Shinde, T. S. Pathan and D. L. Sonawane, Seasonal variations in physico-chemical characteristics of Peth Lake at Ambajogai district, Beed Marathwada Region, India. Journal of Research in Biology, 1(4), 2011, 258-262.

[4] T. P. Naik, K. V. Ajayan and G. H. Lokesh, Physico-chemical characteristics of Kunigal Lake in Tumkur district, Karnataka, India. International Journal Chem. Sci. 10(2), 2012, 655-663.

[5] R. Bahekar and Y. There, Seasonal variation in physico-chemical characteristics of Koradi Lake, district Nagpur, India. Indian Streams Research Journal, 3(2), 2013, 1-5.

[6] A. Mahajan and S. K. Tank, Studies on the physico-chemical parameters of water body- Dara Dam, Maharashtra, India. International Journal of Innovative Research and Development, 2(3), 2013, 751-759.

[7] APHA, Standard methods for the examination of water and waste water. $20^{\text {th }}$ Ed., 1998, American public health Association, Washington.

[8] WHO, Guidelines for drinking water quantity. $2^{\text {nd }}$ Ed., 1993, World Health Organization, Geneva

[9] BIS, Indian standard specification for drinking water. 1991, IS: 10500, Indian Standard Institute.

[10] M.K. Hossain, M.D. Hossain, M.H. Rahman, R. Afza and D. A. Kanom, Physico-chemical condition of two Nursury Ponds at Ishwarganj, Mymensingh. Journal Zoology. Rajshahi University, 27, 2008, 43-46. 
TABLE 1

COMPARISION OF DIFFERENT PHYSICO-CHEMICAL PARAMETERS

WITH SUGGESTED BY WHO AND BIS FOR DRINKING WATER SUPPLY

\begin{tabular}{|c|c|c|c|c|}
\hline \multirow[t]{2}{*}{ S.NO. } & \multirow[t]{2}{*}{ Parameters } & \multirow[t]{2}{*}{ Range Values } & \multicolumn{2}{|c|}{$\begin{array}{c}\text { Standards Permissible } \\
\text { Limit for drinking water } \\
\text { quality }\end{array}$} \\
\hline & & & $\mathrm{BIS}$ & WHO \\
\hline 1 & $\begin{array}{l}\text { Temperature } \\
\left({ }^{\circ} \mathrm{C}\right)\end{array}$ & $16.0-27.8$ & 40 & - \\
\hline 2 & $\begin{array}{l}\text { Turbidity } \\
\text { (NTU) }\end{array}$ & $6-22$ & 10 & $5-25$ \\
\hline 3 & $\mathrm{pH}$ & $7.0-8.3$ & $6.5-8.5$ & $6.5-8.5$ \\
\hline 4 & $\begin{array}{l}\text { Total Dissolved solids } \\
(\mathrm{mg} / \mathrm{l})\end{array}$ & $290-328$ & 500 & 1000 \\
\hline 5 & Total Alkalinity (mg/l) & $138-198$ & 200 & 200 \\
\hline 6 & Total Hardness (mg/l) & $132-187$ & 300 & 500 \\
\hline 7 & Chloride (mg/l) & $20-64$ & 250 & 250 \\
\hline 8 & Phosphate (mg/l) & $0.021-0.071$ & - & 0.1 \\
\hline 9 & Nitrate (mg/l) & $0.21-1.28$ & 45 & 50 \\
\hline
\end{tabular}

